\title{
A Broad Range of Activities
}

If one excludes special contributions and the funds that are redistributed on behalf of foundations and associations, the EPS income in 1995 amounts to about $985 \mathrm{kSFR}$. Of this, some $600 \mathrm{kSFR}$ comes from national societies, $340 \mathrm{kSFR}$ from other forms of corporate membership and from individual members, and $45 \mathrm{kSFR}$ from commercial activities not counting income to Europhysics News, the Society's bulletin. J.L. Lewis, the EPS Treasurer, feels that the very wide range of activities made possible as a result of this income is not always appreciated.

\section{- Division and Interdivisional Groups}

Each of the Society's 14 Divisions and Interdivisional Groups carries out a variety of activities covering conferences, prizes, newsletters, coordination networks, peer review, etc. related to their specialities. The EPS Secretariat is often called upon to help, especially when it comes to administering membership and mailing lists, organizing elections, promoting conferences, providing Internet-based services, channelling applications for funds to international bodies, establishing programme committees and editorial boards, etc. Most of the Divisions and Groups organize annual or biennial meetings, sometimes in collaboration with other international organizations (see 1996 EPS Organized and Sponsored Conferences at the end of the section Information to EPS Members). In the case of the Condensed Matter Division representing about one-half of the membership, the Division's annual General Conference is held every third year in collaboration with the French, German or UK societies, while four of its Sections hold series of meetings, often on a regular basis.

\section{- General Conference}

The EPS General Conference "Trends in Physics" is held every three years. It allows eminent scientists to present the latest developments to a general audience that includes young physicists who are starting out on their careers. It is usually organized by a national society or societies, with EPS being responsible for the programme.

\section{- Education Activities}

The European Mobility Scheme for Physics Students (EMSPS) which the Society set up and supervises enables students to study at a university in another country while retaining the course credits. Mobility stays have been funded by special donations and by grants from the European Union's TEMPUS and ERASMUS (now SOCRATES) programmes. A staff member is employed full time to administer the scheme.

The Interdivisional Group on Physics Education aims to coordinate mobility activities under a general framework that includes its Forum on Education and a section dealing with university teaching. Special meetings are planned, including a symposium at the next General Conference on aspects of physics education.

\footnotetext{
- Physics and Society

General aspects of the interaction between the physics community and society at large
}

are handled by the Action Committee for Physics and Society. It holds regular workshops on topics such as employment, energy use and the public understanding of science. Most are based on surveys carried out in advance in collaboration with national societies and lead to a publication.

\section{- Links with Industry}

Links with industry have long been recognized as an important aspect of the Society's work. A former action committee led to the establishment of the Interdivisional Group for Applied Physics and Physics in Industry. It organizes the very successful Europhysics Industrial Workshops that bring together university and industrial physicists working on specific topics in emerging new technologies. There has been in the past special activities for EPS Associate Members which include a wide range of industrial companies. The annual meeting with the Associates will now be incorporated into the work of the Group. Other Groups, notably the Group for Experimental Physics Control Systems, also have special links to industrial partners.

\section{- EPS Lecturer}

The Society organizes a series of open lectures throughout Europe by a distinguished EPS Lecturer.

\section{- East-West Activities}

Regular meetings are held with representatives of national societies from east and central Europe (E\&CE) in order to initiate and coordinate general initiatives covering such topics as student mobility, conferences, publications, science policy, and science management. The society has established special arrangements for distributing Europhysics News in the region and grants are provided to support young physicists attending the General Conference.

\section{- Qualifications}

Qualification activities are organized through the Action Committee for Conferences, the Action Committee for Publications and the Register Commission for the

\section{EPS-10: Trends in Physics} 10th GENERAL CONFERENCE OF THE EUROPEAN PHYSICAL SOCIETY

9-13 September 1996 - Sevilla, Spain

Organized by: The Royal Spanish Physical Society The Portuguese Physical Society

Secretariat: PROCONSUR, Edificio Capitolio, Avda. San Francisco Javier, 15 E-41018 Sevilla, Spain

Tel: $+34-5-4922755$ Fax: +34-5-492 3015 Email:eps10@cica.es - WWW:http/epswww.epfl.ch
Published by EPS to inform members. Editor: P.G. Boswell, EPS, BP 69, CH-1213 Petit-Lancy 2. E-mail: peter.boswell@cern.ch Tel.: +41-22-7931130 - Fax: +41-22-7931317

\section{NOVEMBER - DECEMBER 1995}

European Register of Physicists. They include conference sponsorship, the EPS Recognized Journal qualification, and most recently, professional qualifications which have involved working with the European Commission (EC) on the recognition and granting of Eur Phys, a designation that is increasingly appreciated by members. The Conference Committee also coordinates Division and Group proposals to the EC for support, either as EC-sponsored events or as EC-funded European Research Conferences in Physics co-sponsored by the European Science Foundation.

\section{- Prizes}

In addition to helping administer the HighEnergy and Particle Physics Prize, the Quantum Electronics Prize, and the Accelerator Prize, the Secretariat manages the annual Hewlett-Packard Europhysics Prize. The Amaldi International Prize for high-school textbooks is awarded in collaboration with the EPS Forum on Education.

\section{- Administrative Services}

The Secretariat's records of membership represent a major contribution to the work of the Divisions and Groups because they serve as their links to members of national societies. The Secretariat also handles, under contract, the Secretariat of the European Astronomical Society (EAS) which is in partnership with EPS in the Joint EPS-EAS Astrophysics Division. Up to 25 scholarships to EPS sponsored Erice schools are administered by the Secretariat each year along with Heraeus Grants for young physicists to attend EPS organized meetings, and Mayer Foundation Grants for scientists from E\&CE.

\section{- Publications}

The Action Committee for Publications encompasses working groups that promote European physics journals and harmonise standards and systems of interest to physicists covering all aspects of publications. These activities lead to regular workshops and reports. The committee advises on EPS publications and coordinates its work with the Internet Coordination Group that develops and supervises the Society's EurophysNet World-Wide Web (WWW) service.

Europhysics News is the major vehicle by which the national societies and the individual membership are kept in touch with one another. It is currently published six times a year and is distributed to the membership, either directly to Individual Ordinary Members or indirectly through national societies unless special arrangements are made. Europhysics News also takes charge of various information sources that are distributed in parallel via WWW such as the Europhysics Meetings List, the Europhysics Directory of Large Facilities in Physics (which is supported by the $\mathrm{EC}$ ) and the EPS Directory.

Europhysics Letters is a letters journal 
published by a partnership between EPS and 16 national societies. EPS handles business management as well as manuscripts up until acceptance for publication. It is significant that as a result of the arrangement the venture generates income, with a new issue appearing every 10 days.

The European Journal of Physics publishes scholarly articles for university staff. Initiated by EPS, it is a very successful parthership between the EPS and the Institute of Physics Publishing that brings income.

The Europhysics Conference Abstracts series of extended abstracts of Divisional Conferences are published by EPS in collaboration with conference organizers.

\section{- Special Activities}

In recent years, two administrative responsibilities have been undertaken by the Secretariat. First, the International Association for the Promotion of Cooperation with Scientists from the Independent States of the Former Soviet Union (INTAS) provided EPS with some half million Swiss francs in 1994, and again in 1995, for the provision of journals to the FSU. Second, the Soros Foundations provided $350 \mathrm{kSFR}$ in 1994 and the same in 1995 to facilitate the movement of students from East and Central Europe within the framework of the EMSPS scheme.

\section{- New Activities}

The Solidarity Fund financed by a levy on participation at Divisional conferences is administered by the Secretariat. It has been established to provide seed money for new conference series and to make it possible for people from economically poor parts of Europe to attend EPS conferences, workshops and schools.

The Lapereau Fund was established recently, with an annual budget of SFR 10000 , so that small sums could be made available at short notice during the year for an activity that was not included in the budget approved each year by Council in March. In this way the Society can give encouragement to lapereau (French for "little rabbit") that might grow into something larger.

\section{EPS CONSTITUTION}

\section{Executive Proposes Amendments}

\section{- Article 1 (Legal Basis and Seat)}

At its meeting on 24-25 March 1995, the EPS Council accepted an Executive Committee proposal that the Society consider consolidating its Geneva and Budapest Secretariats in a European Union Member State. The Executive Committee then set up a working group to report in June on possible alternative locations for the Secretariat (it is presently split between a Secretariat in Geneva and another in Budapest) and a request for proposals was sent to National Member Societies. Offers were received from Amsterdam, Graz, London, Mulhouse, and Vienna, and from a science park located on French territory beside Geneva. On the basis of the working group's recommendations, the Executive Committee decided in June to recommend moving the Secretariat and to seek further information with the aim of having a final proposal in November. Meeting on 17-18 November in Budapest, the Executive Committee accepted the working group's recommendation to move the Secretariat to a science park located near the University of Mulhouse on the outskirts of Mulhouse in France.

The Executive Committee plans to propose this move of the Secretariat to Mulhouse to Council on 22-23 March 1996. If Council accepts the proposal (by a two-thirds majority of those present and voting), it will have to take a formal vote on changing Articles 1.1 and 1.3 of the EPS Constitution. Since any amendment of the Constitution must be communicated to members at least three months before Council shall decide on a proposal, the present Articles 1.1 and 1.3 and the proposed amendments are given below. - Present Article 1

.1: "Under the name of European Physical Society (EPS), an association has been organized and incorporated; it is governed by Article 60 and the following of the Swiss Civil Code and by the present Constitution."

.3: "Its seat is in Geneva, Switzerland."

- Proposed Article 1

.1: "Under the name of European Physical Society (EPS), an association has been organized and incorporated; it is governed by Article 21 and the following of the Local Civil Code (Alsace/ Moselle)."

.3: "Its seat is in Mulhouse, France."

\section{- Article 21 (The Executive Committee)}

The Constitution's formulation of eligibility to serve as the EPS President is slightly contradictory. The Executive Committee will propose to Council the following amendments to Article 21 of the Constitution:

- Present Article 21.3 shall become Article 21.2 and the first sentence which reads:

"The President shall be in office for two years." shall read:

"The President shall be in office for no more than two years."

- Present Article 21.2 shall become Article 21.3.

If Council accepts the amendments, the decisions will be communicated in writing or in an equivalent form to all members. A mail ballot of Ordinary Members is required if oneeighth request within 40 days that a decision be submitted to the EPS General Meeting.

\section{EXECUTIVE COMMITTEE DECISIONS}

The Executive Committee of EPS decided the following at its meeting in Budapest on 17-18 November 1995:

- EPS Constitution: To propose to Council in March 1995 that the EPS be established as an association under the law of Alsace/ Moselle. To propose to Council to rectify a minor contradiction in the Article governing the term of office of the President. (see above for the statutory announcements to members).

- EPS Secretariat: To propose to Council that the EPS Secretariat be consolidated on site in Mulhouse by moving the Geneva Secretariat at some date after the EPS-10 General Conference in September 1996 and by a phased running down of the Budapest Secretariat. The move from Geneva would take place independently of whether or not the editorial staff and business management of Europhysics Letters, representing about one-half the total Secretariat staff, also moves. To consult with National Member Societies before the proposal to Council.

- Finances: To accept the Treasurer's report that envisages a provisional surplus of some 41 kSFR in 1995, which would reduce the deficit (subject to the 1995 audit) to 21 kSFR. To accept a proposed budget for 1996 based on the Secretariat not moving and which envisages a surplus of $30 \mathrm{kSFR}$, with expenditures broken down according to activities. A revised budget would be prepared if Council agrees to move the EPS Secretariat.

- European Union (EU): That the President formulate a statement to the EU Commissioner for science suggesting ways to improve the EU's science policy.

- EPS Lecturer: To accept the nomination by the Quantum Electronics and Optics Division of A. Zeilinger as the next EPS Lecturer.

- EPS Prizes: To propose to Council that the regulations of EPS Division and Group prizes contain a statement to the effect that the final recommendation (of the awarding body) is submitted to the Executive Committee for ratification within a few days, together with a short description of the motives.

- Europhysics Letters: That E. Osnes serves as the Chairman of, and the Executive Committee representative to, the Management Board of Europhysics Letters as from 27 November 1995, replacing N. Kroó, whose term of expires, as delegate, and A.M Hoogenboom, the representative of the junior partners, as Chairman.

- National Member Societies: To accept applications, subject to Council's approval, for National Society Membership from societies and associations based in countries that already have a National Member Society.

- Honorary Members: To propose to Council four nominations for election.

- European Physicist: To approve the nomination by the Register Commission of 21 appointments to the European Register of Physicsts. To accept the Commsssion's proposed Code of Conduct for European Physicist and the proposal that appeals be referred to the EPS President.

- Mobility Scheme: To accept five new participating institutions, bringing the total number to 174. To appoint E. Elbaz (Lyon), the Mobility Commiteee nominee, as the Vice-Chair replacing $\mathrm{E}$. Heer (Geneva). H. Latal (Graz) remains in the Chair.

- Conference series: To accept the Conference Committee's proposal that conferences in a series that moves from time-to-time out of Europe can be sponsored by EPS if there is at least one delegate of a Division or Group on the programme advisory committee when the conference is held outside Europe, and at least one delegate on the Programme Committee when it is held in Europe.

- Publications: To accept a recommendation from an ad hoc working group of the Publications Committee that EPS consider a proposal to supervise a distributed system of servers for prepublications.

- EPS-10: To accept a proposal from the European Astronomical Society that it sponsor symposia on space physics at the 1996 EPS-10 General Conference.

- EPS-11: To await Council and Executive Committee decisons on moving the EPS Secretariat to Mulhouse before deciding upon the venue and date of the EPS-11 General Conference. 